\title{
James M. Decker's forced thought of an end to ideology in George Orwell's 1984
}

\author{
Dr. Mariem Khmiri \\ The Higher Institute of Applied Studies in Humanities of Sbeitla, University of Kairouan, Tunisia \\ merriemkhmiri@hotmail.com \\ Received: 06 Apr 2021; Received in revised form: 26 May 2021; Accepted: 12 Jun 2021 \\ (C)2021 The Author(s). Published by TheShillonga. This is an open access article under the CC BY license \\ (https://creativecommons.org/licenses/by/4.0/)
}

\begin{abstract}
James M. Decker examines 1984 under a skeptical lens as a statement in favor of capitalist democracy: which according to him thrusts Orwell forthright in the mist of ideology. A more compelling question, however, would be: Why was the interpretation of Orwell's 1984 mostly a trudge against one particular version of totalitarianism called Stalinism? Isn't it a form of complicity to always ground totalitarianism in Stalinism (thus also masking the totalitarianism exerted elsewhere in the world)? It seems it is not the Inner Party employing ideology to keep the masses under control as much as James M. Decker who provides an entrance into 1984 within a paradigm which excludes any possibility of meaning outside his apocalyptic landscape of a humanity not less thoughtless than out of history.
\end{abstract}

Keywords-end of history, end of ideology, post-totalitarianism, forçage.

\section{LITERATURE REVIEW}

In a syllogistic formula in his book, The End of History and the Sane Man, Francis Fukuyama displays his positive view of liberal democracy as the culmination of man's mastery over his universe. Arresting, however, is Fukuyama's reference to a world system as established as liberal democracy with the substantive ideology. Surprisingly enough, his use of this substantive will be dissected within his idiosyncrasy which hails liberal democracy as the strongest scoff at some peoples' surrender to the manipulative practices of the totalitarian economy. Fukuyama legitimates liberal democracy as ideology only insofar as the term stands for what grants sovereignty to the individual self against the sweeping tide of totalitarianism as the world's ruling economy during a certain period of time (ibid, 45). However, technical-cumethical accountability of some critics becomes subject of disbelief when James M. Decker (for example) chunks the entire idea of Fukuyama only to dwell on the latter's declaration that no ideology on earth is in a position to outshine liberal democracy. The way he works on his theory about an end to ideology discloses Decker's abuse of Fukuyama's lofty Nietzschean un-historical pursuit within the latter's reinvention of the theme of ideology.
Decker's inability to cross the threshold between totalitarianism (as a past time reference) and posttotalitarianism (as the next time reference which also stands for the bloom of capital democracy) keeps him trapped in self-contradiction. Why? It is because he visualizes an end to ideology while he also reflects on the endurance of ideology in Oceania as a "reality". Ironically enough, Decker's seesawing movement between ideology and its opposite is made loud in his attempt to fog this indecision by projecting it on Winston (page 139 in Bloom's book). We still have a feel of Decker's indecision where on page 16 in his own book: Ideology, he admits to the boundedness of the subject to the material world, therefore to the very workings of ideology:

"Subjectivity does not arise merely from the physical ability to think; it grounds itself in the material. The subject, thus, functions not as a truly free agent, but as a phenomenon bound by specificthough flexible - parameters." (Decker 2004, 16)

Decker is acknowledging that a person's ability to think is not enough to grant them autonomy: a remark which reveals Decker's consciousness of an extant crisis between the individual (on the one hand) and an ensemble of forces 
that are beyond his ken (on the other). However, later on (in the part which appears in Bloom's collection of articles), Decker also finds a systematic correlation between the end of ideology (on the one hand) and the end of history (on the other). So, how can we account for this ambiguity typical of the Decker line of thought?

In his article: "The Dual Purpose of Animal Farm" (Bloom 2007, 145), Paul Kirschner discards the fetish for literality the way it has occurred to Decker. Kirschner observes an underlay to the immediate impression left by Orwell's literature. This underlay according to Kirschner:

"was artistic as well as political [...] The appealing form of such stories, adopted by Orwell, interfered with the full and accurate expression of his political thought." (qtd in Bloom 2007, 145)

Kirschner suspects that Orwell's literary representation is a means to camouflage the author's very political obsession. In this respect, Kirschner is also joining the camp of Rob Kroes who excoriates the manipulative strategy of the Inner Party on the grounds of its "dislocation of human understanding by linguistic sabotage" (Kroes 1985, qtd in Decker 2004, 133). One difference between Kirschner and Kroes, however, is that the former will expatiate upon this very meditation until he arrives at the conclusion of a dilemma as the leading thought about Orwell. A closer ally of Kirschner would be William E. Cain who stigmatizes Orwell also as a pervert.

\section{Research questions}

The article is an attempt to answer the following questions:

1- How can James M. Decker emit a hypothesis about an end to ideology in Oceania heedless of the role performed by Orwell's text as a metaphor?

2- To what extent can we relate Decker's clock to the historical reality of post-totalitarianism?

3- How can the argument made by James M. Decker be validated while actually proven to have modified Francis Fukuyama's argument about history as security to his hypothesis of an end to ideology? In this case, what academic accountability did earn James M. Decker the privilege of having his article edited by Harold Bloom?

4- How felicitous was Decker's (among others') probing into Orwell's ideological background?

\section{INTRODUCTION}

Decker's crippling thought about politics as Orwell's ultimate message delays the access to the Orwell literature as an aesthetic experience. Maintaining that totalitarian ideology has vanished from the post-totalitarian world of Oceania reveals the discord in Decker's mind between literality and metaphor. Decker also extends his discussion to the certainty that resistance in 1984 (while proven inefficient) nullifies the sense of history from the events of the novel because of the actual elapse of totalitarianism as a time reference. This is another vintage point where to spot the absurdity of Decker's focus on history in the sense of a chronicle: therefore never as a new temporality predicated on the individual as potential.

Orwell manages to present us with the consequences of manipulative governments in the East and West where no prospect of creativity is available to their peoples. And yet, Orwell's treatment of this crisis of creativity in the post-totalitarian phase is not conductive to the truth that the author is also ideology-ridden. This is another instance where the Decker argument degenerates into the category of metaphysics of presence.

Decker has a serious problem understanding the idea of the end of history the way it has occurred, for example, to Francis Fukuyama. Decker rushes into linking posttotalitarianism (precisely the nascence of capitalism) with the end of history. For Fukuyama (among other critics), history crumbles to nothingness when the people becomes absorbed by such issues as pollution and addiction, i.e., when there is no concern with the intellectual activity of the people in these capitalist societies.

To lend credence to his idea of history, Decker observes the life of the citizens of Oceania as a concentration within the now-point of the present. He sees in this concentration a moment of stasis. However, the truth about the present moment in modern thought is its disconnection from the past of a nation (as a repressive kind of legacy) while it also projects towards the future as potential. The present therefore (and contrary to Decker's hypothesis) is the fullest concretion of history and consequently, of the individual's self-affirmation. The pathological time-consciousness imposed by the posttotalitarian government on the citizens of Oceania in 1984 can be taken as an image of the pervasive effect of party allegiance but is also (and by the same logic) a reflection of ideology: whether it is that of the totalitarian oppressor or of the nascent capitalism. Either way, we cannot link this post-totalitarian clock to an end to ideology.

While postulating his thought about death of ideology, Decker fails to provide an alternative to it within the inexorable movement of history and consequently, of ideas. Similarly, when attempting to offer insight into Fukuyama's concept of ideology, Decker is still incognizant of the latter's interpretation of the meliorative 
role of ideology as a motivational force towards individual self-improvement: therefore as a benediction in disguise. The technical infelicity in his reading of Fukuyama teases out the truth about the correlation made by Decker between death of history and death of ideology as what not infrequently degenerates into a falsity.

\section{Orwell and the charge of complicity with liberal democracy}

An unsettling question is thorough-going in some parts of James M. Decker's book: Ideology about what he regards as the death of ideology in Orwell's 1984. This death of ideology, in the Decker optic, is materialized in the representation of the desperate resistance by such rebels as Winston Smith and Julia: a representation which (still according to Decker) circumcises the aesthetic weight of the text and leaves the reader with a very cumbersome style as its dominating truth (Bloom 146-173). This feel of impotence left by the dysfunction of resistance is where ideology (according to Decker, I insist) is at a stalemate. Decker also correlates the death of ideology with the death of history: "Oceania contains no endings, no beginnings, no history" (Ibid 150). We understand how apocalyptic is the portrait canvassed by Decker for Orwell's posttotalitarian Weltanschauung in 1984: "Orwell conceptualizes the end of history as a grim, vacuous realm where struggle has ceased and canine-like contentment is omnipresent" (Ibid). Juxtaposing end of ideology side by side with end of history not only obscures the metaphoric import of Orwell's text but also (ironically) betrays Decker's absolutist resistance of the new sense of history flowing from 1984.

In an article titled "George Orwell's 1984 and Political Ideology" quoted in Bloom's edited criticism of Orwell, Decker persists on indicting what he discusses as Orwell's ideological bias. Decker lays a marked emphasis on Erich Fromm in this respect:

For Fromm, Orwell excoriates the capitalist West for many of the same tendencies evident in totalitarian states, claiming that 'managerial industrialism, in which man [sic] builds machines which act like men and develops men who act like machines, is conducive to an era of dehumanization and complete alienation.' (Fromm, qtd, in Bloom 2007, 134)

Erich Fromm is aware of the connection between the economic growth of a world superpower (on the one hand) and psychological manipulation (on the other). He goes on with the precision that manipulation (what Fromm calls "conditioning", (Fromm 2008, 351)) in the western context takes the form of reward, motivation, and the attraction of consumers. However, in the East (and despite potential economic growth), manipulation veers towards terror (albeit not immediately sensed). Finally, Erich Fromm foresees the future in both contexts in terms of the peoples' compliance with the rules of the system which also means that no creativity is achievable by these peoples (Fromm 2008, 351). Such regressive portrait of men as mere cogs in the managerial machine of state economy is also articulated in Orwell's 1984 at least on its surface level.

Despite the tug-of-war in 1984 between the totalitarian machinery of the State (on the one hand) and people's resistance (albeit desperate) (on the other), Decker keeps pointing an incriminating index to what he takes as Orwell's “dual purpose” (Bloom 2007, 134): a serious charge of complicity with the very totalitarianism Orwell has set out to criticize. In an attempt to back up his argument, Decker quotes Anthony Easthope's idea that liberal economy legitimates infractions of democracy through state interventionism as well as the perpetration of injustices against the labor force:

In a three-superpower world (Eastasia/ China represents the third power), totalitarianism has spread far beyond its Stalinist roots. Antony Easthope validates such a perspective, observing that liberal democracy is complicit with the totalitarianism it would condemn in that it supports the undemocratic structures of corporate capitalism and state paternalism. (Easthope qtd, in Bloom 2007, 134)

A fair point was made by Decker such that Orwell's attack against Stalinism in 1984 is also valid for the other two world-superpowers: namely China and the USA. However, Decker's other hypothesis about Orwell's implication in the ideology of the totalitarians (what Decker describes as "dual purpose" (Bloom 2007, 134) is a sign of Decker's suspicious objectivity: which also obstructs the more luminous truth about Orwell's text as a renewable possibility of meaning. One necessary step to invalidate Decker's wide-eyed platitude is to take Orwell's text as a metaphor.

\section{Decker's dilemma also known as the end of ideology}

My orientation while approaching this dilemma is towards scrutinizing the quality of quotes cited by Decker especially from Fukuyama regarding East versus West power relations and the concomitant dissemination of ideology worldwide. Decker also quotes Fromm's point of view such that the danger of totalitarianism is independent from ideology (communist and capitalist) and this 
(according to Decker) is due to "the demise of free market capitalism" (Decker 2004, qtd, in Bloom 134) as an obtrusive historical evidence. I think that Fromm's point is not in full concord with Decker's interpretation. I even consider that Fromm's statement: "the danger [of totalitarianism is] ... relatively independent of ideology" (Fromm 1983, qtd, in Bloom 134) — has been misplaced by Decker only in furtherance of the latter's moralistic mystification of his idiosyncratic hypothesis called death of ideology.

In some instances, Decker has pushed his interpretation of Fromm's idea about totalitarianism out of proportion: "One might, in fact, posit that Orwell's use of totalitarianism predicates itself on the end of ideology" (Decker qtd, in Bloom 134). Decker takes the perilous leap of making a projection -what I aptly call a forçage-of what he conceives as end of ideology upon another concept: namely the end of history. However, because the end of the history of capitalism was contingent on the factual dwindling of capitalist democracy (while the end of ideology is rather difficult to outline as a concept), I speak of a forçage due to the heterogeneity of the two notions as shall be elucidated in this chapter.

Fromm's quote shows the danger of totalitarianism as the ideology and practice which filigrees capitalism and communism indiscriminately. Fromm's meditation is such that the threat of ideology is the kind of reality which exists heedlessly of whether it is developing in the East or West. Fromm's holistic contention about communism and capitalism is that both are grounded in "industrialization, their goal is ever-increasing economic efficiency and wealth" (Fromm 2008, 350). In this light, we come to grips with Fromm's skepticism about capitalism and communism as what hardly departs from a materialistic interest (ibid). One thing to be brought under an inquisitive lens is the rationale behind Decker's frenzied enthusiasm about finding an end to ideology. The inception of this platitude made by Decker can be traced back to his distorted idea when it comes to the link between history and ideology in the first place.

While attempting to test Decker's observations which licentiously cross the line between the end of history and the end of ideology another question arises: What does Decker mean by the end of ideology at all? Is it really Fromm's deliberation he is perverting or maybe Fukuyama's? Let us take a look at this line quoted by Decker from Fukuyama:

"There is now no ideology with pretensions to universality that is in a position to challenge liberal democracy." (qtd, in Bloom 2007, 148)
Fukuyama presents us with the kind of truism which takes the now-point of the present as a reference to measure the impact of ideology: a universal epidemic whose main form is liberal democracy. Not only is this economic trend spread worldwide but -in the Fukuyama logic - it is also the only universal phenomenon which mocks its economic quality into psychological manipulation. The superlative structure in the above claim made by Fukuyama refers us immediately to the latter's idea about the gravity of the danger presented by capitalist democracy. The same reflection is shared by Decker who finds in capitalist democracy an insidious vehicle of ideology. However, before we move any inch further, let us recall Fukuyama's unabridged statement as it originally occurs in his book The End of History and the Last Man:

There is now no ideology with pretensions to universality that is in a position to challenge liberal democracy, and no universal principle of legitimacy other than the sovereignty of the people. (Fukuyama 1992, 45)

Fukuyama's syllogism strikes a balance in terms of power relations between free market economy (on the one hand) and the sovereignty of the people (on the other). What I also make out from this syllogism is the continuity of ideology both ways: that is whether it takes on the vesture of a world economy or of a socio-political movement of resistance. Either way, ideology for Fukuyama never comes to a close. Now the question remains: Why did Decker remove the coordinated clause (i.e., the second half of the entire sentence) to present his audience only with one part of Fukuyama's original statement? In other words, why does Decker insist on interpreting Fukuyama's analysis of the East vs. West map essentially in parallel with the death of ideology? What might underlie this hasty collage in Decker's mind between the death of history and (what he visualizes as) the death of ideology? We begin to approach his misconception when he says that counterideology is non-existent in post-totalitarianism and all that is left is the death of ideology. When he refers to the posttotalitarian behavior towards younger generations, then the confusion in Decker's mind between end of history and end of ideology is readily within sight:

"Counter-ideology is invisible, particularly among children and young adults who, of course, were born after the Party's hegemony was complete. As O'Brien tells Winston, the Party 'cut the links between child and parent" (Decker, qtd, in Bloom 2007, 140) 
With regard to the discussion at hand about Decker's selfcontradiction, his consideration that: "Winston exists at the margins of the party, but he never leaves the circle itself" (qtd, in Bloom 2007, 142) betrays his obsession with ideology while he is unsure whether totalitarianism has actually vanished from the Orwell aesthetics or whether it still haunts his characters and readers alike. "In Orwell's formulation, once the threshold of totalitarianism has been passed, a return to ideological struggle is impossible" (ibid): this is the kind of overgeneralization that invites a review of Decker's understanding of the term ideology per se and of what he describes as "the threshold of totalitarianism" in the first place. Still, if the lastmentioned metaphor is a vintage point invented by Decker, then we are clearly at a loss where to situate this vintage point on the map of ideologies or at least on the historical timeline. This feeling of loss is the immediate result of Decker's impulsive attempt to dodge the truth about people's undying adjustment to ideology. Decker is incessantly plighted with inconsistency:

"While Fukuyama argues that totalitarianism is a historical aberration that represents a 'pathological condition' that will inevitably be corrected, Orwell's dystopia presents a stark counterpoint that explicitly maintains the 'condition' could become permanent if other ideologies are rendered unthinkable." (Decker, qtd, in Bloom 2007, 142)

My question is: Where does Decker ground his assumption that other ideologies can ever be "rendered unthinkable" in the Orwell literature? And if so: that is in case one ideology outperforms others (which is also one of the possible readings Orwell's 1984 permeates), then we are ipso facto miles away from what he has referred to earlier as on as "the death of ideology". Decker's problem is basically one of logic.

Decker's claim in this last quote can be depleted if we consider that "valorizing the liberal subject" (ibid) is paradoxically born from the very mental idleness of the citizens of Oceania. I find that those citizens are -contrary to Decker's opinion-far from being "unconcerned with individuation" (ibid). One problem with Decker is that he freezes his line of thought within the literal denotations of the socio-political Weltanschauung discussed in 1984. The portrait drawn by Orwell allows for the very antithesis of the point made by Decker. The "contentment" diagnosed by Decker in Orwell's human figures is only an impression: it is even a value judgment inflicted on the text from without, hence my aforementioned idea of a forçage: that is of an act of violence exerted by Decker who dwells on literality and rescinds the truth about the survival of ideology in literature and elsewhere.

Decker's hope "for the return of ideological chaos and its attendant humanity" (Bloom 2007, 143) is the revelation of his non-comprehensive reading of Orwell because the chaos of ideology does inhabit life in an obsessive way whichever direction we take: otherwise how could we ever speak of resistance? "All sense of irony has been banished" (ibid): this is the very apex of Decker's entrenched resistance to the metaphoric import of 1984 while the Orwell depiction of stasis is irony itself.

\section{Decker vs. Fukuyama: the battle of history vs. ideology}

When emphasizing only one part of Fukuyama's entire reflection on the "bankruptcy of ideas", Decker was prejudiced towards injecting this part into the history of totalitarianism as if by force. One thing is that Fukuyama employed this metaphor of "bankruptcy of ideas" within a holistic explanation of the disparity between the Communist Left and the authoritarian Right with the precision that each system of government has its "ups and downs" (Fukuyama 1992, 39). Decker's misjudgment comes into view clearly in terms of his own ideological bias: which underlines his excoriation of Orwell's novel while the entrance he makes into Fukuyama's argument also falls forfeit.

A serious flaw of logic is when Decker misinterprets Fukuyama's speculations about the future of capital democracy:

"Fukuyama posits that liberal democracy (usually of the capitalist variety) echoes the innermost desires of humanity and, in its purest form, will mark the end of history. Although 'a host of problems like unemployment, pollution, drugs, crime, and the like' will still exist, the absence of any 'deeper sources of discontentment' will preclude a return to history and its ideological posturing." (qtd, in Bloom 2007, 135)

As we read in Fukuyama's string of words directly from his book The End of History and the Last Man, we make out that the prospect of an end to history looms large in capitalist countries only if their ultimate preoccupations are with such issues as drug addiction, pollution, unemployment, etc. Unless the liberal mind embarks on deeper thoughts: what Fukuyama refers to as "contradictions [...] whether life is truly satisfying" (Fukuyama 1992, 288), history will virtually come to a standstill. This is Fukuyama's controlling awareness about the end of history for democratic capitalism: an end which 
yet does not predicate itself on the failure of totalitarianism in a systematic way: "Certainly, we cannot take the collapse of communism as a proof that no future challenges to democracy are possible, or that democracy will not one day suffer the same fate" (ibid). Fukuyama envisions the apocalypse of history as something endocrinal among capitalist countries themselves: that is functioning in the same way as a gland whose secretion is channeled inside an organism: not outside. What I understand is that Fukuyama diagnoses the challenges to the development of the historical sense in the western hemisphere as a function of an existential crisis among its people when life hardly exceeds such vegetative contingencies as pollution and addiction. The dwindling of communism in the other hemisphere, Fukuyama tells us, is not the booster of the historical timeline for the capitalists in a systematic way.

While Fukuyama maintains that the fate of the two hemispheres is somewhat different, Decker entrenches his assumptions upon a symbiotic co-dependency between the death of totalitarianism (therefore what Decker theorizes as the death of totalitarian ideology on the one hand) and the death of history in the capitalist world (on the other).

\section{Misreading Fukuyama: Decker's crisis with post- totalitarianism}

The absence of a clear sense of the post-totalitarian episode replayed in 1984 is the case for Decker who insists that Fukuyama interprets post-totalitarianism in 1984 strictly as anti-totalitarianism:

"Opposing Orwell's vision of
totalitarianism, Fukuyama holds that 'the
most fundamental failure of
totalitarianism was its failure to control
thought' (Fukuyama 1992, 29). While
doublethink and thought-crime might
serve for interesting fiction, Fukuyama is
clearly skeptical of their practical
applications. Despite concerted attempts
to exercise state authority within the
confines of the human mind, the innate
need for [...] self-recognition undercuts
efforts to control individual imagination
(162)." (Decker, qtd in Bloom 2007,
135)

Decker's take on how Orwell exposes state control in the totalitarian government unveils how the former always overlooks the deeper truth about Orwell's fiction as a metaphor. Most blatant about Decker is also his failure to highlight the unending potential for man within Orwell's macabre narrative. An example of such potential can be found in Winston's rebellion which - although it brings forth laughter rather than indignation in the Inner Partystands out in its metaphoric aspect about the embattled will of the individual (on the one hand) colliding with the crushing will of the totalitarian authority (on the other). Similarly, Julia's resistance "from the waist downwards" cannot be incorporated in the category of the burlesque and is (in my optic) another expression of human potential elbowing its way into prominence in defiance of Stalinist dictatorship. The same holds for what Decker describes as the "instinctive emptiness" (Decker, qtd in Bloom 2007, 141 ) in the case of Winston who initially fails to have an erection with Julia. The body, in my sense, is another vector of man's anger at the bureaucracy of the State. Similarly, the benumbing effect of Julia falling asleep upon hearing The Theory and Practice of Oligarchical Collectivism read to her by Winston is an additional ingredient to the metaphoric underlay of the text vexing its own literality.

“The country's political machinery is exposed to Winston, but without a viable counter-ideology he lacks the critical vocabulary to articulate alternatives and work toward their realization" (Decker, qtd in Bloom 2007, 141-42). Contrary to Decker's pessimism, I find in these scenes from 1984 the actual carrier of "alternate ontological possibility" (the expression is used by Decker on page 136 from Bloom's collection of articles) to the individual. Decker's misreading of Fukuyama is an indication of the former's focus on Orwell's text essentially as an array of historical sketches: "For Orwell, however, the end of history is far from the sunny paradise that Fukuyama envisions" (Decker, qtd in Bloom 2007, 136). To say that Decker's fixation on literality verges on obsession is an understatement: "The narrative [...] presents a horrifying vision of the consequences of absorbing an ideology so completely, so unquestioningly, as to eliminate ideology altogether "(ibid). The end of history portrayed in the novel is not immediately synonymous with an end to ideology: the potential of thought has been there all the way.

The leveling merit of this finding by myself works to the very disadvantage of Decker's argument which is also thoroughly beside the point made by Fukuyama. Decker also pushes plausibility to an extreme when he implicates totalitarianism in (what he conceives as) the murdering of ideology: "the regimes engage in the simulacrum of war in order to prop up an obsolete class structure" (Decker, qtd in Bloom138). Decker's idea about post-totalitarianism is barren and forcée: "Although the system that Oceania represents is definitely suggestive of totalitarianism, it would be better characterized as posttotalitarian" (ibid, 137). Taken from the side of logic 
alone, if the ruling system of Oceania is post-totalitarian, then, it necessarily bears within itself the seeds of totalitarianism or at least the reverse of those seeds. In this light, Decker's point about the total death of totalitarianism as ideology shrinks to nought.

\section{Decker's misconception about the now-point of the present in 1984}

O'Brien's catechistic remark to Winston about the relationship between ideology (on the one hand) and the historical time-consciousness of the people (on the other): "who controls the past controls the future; who controls the present controls the past" (Orwell 1983, 204) - is the telltale about the survival (also the efficiency) of ideology in how it freezes the subjugated people on the timeline. Building on O'Brien's remark about the blurred lines between all time references in the minds of the citizens of Oceania, this state of paralysis is the imminent consequence of ideology which undercuts the subject's sense of temporality and leaves them contented with the timeline imposed by a will exterior to their own.

Contrary to Orwell's clock, Decker seems to have quite a metaphysical time-consciousness: "The Party has, in effect, ruptured the very fabric of time and rendered it meaningless outside of the present" (qtd in Bloom 2007, 139). One thing is that the present is not in the slightest the most defining time-reference for the population of Oceania because the present (from a Nietzschean also a Bergsonian perspectives on man's relation to time) is the sole nexus connecting man to his universe: therefore the strongest form of self-affirmation. Following Decker's structure of belief that history has reached its end in the posttotalitarian world of 1984 , then how can we ever speak of the persistence of the now-point of the present? The issue, again, is obviously one of logic. Finally, O'Brien's metaphoric suggestion to Winston that the Party "cut the links between child and parent" (ibid, 220) is another symbol of an irreparable rift between past and present within the communists' time-consciousness. Because of its un-relatedness to the present, the timeline of a communist subject is not only out of history but is also (and more alarmingly) sunk in a bottomless state of a-temporality.

That "the inhabitants of a totalitarian society eventually come to believe in the very government that injures them" (Decker, qtd in Bloom 2007, 137) is a factor more suggestive of their vacuous time-consciousness even with the demise of the totalitarian system of government. The endurance of party allegiance is symptomatic of the ubiquity of ideology that has infused the life and minds of partisans and opponents alike. However, because it is ideological, the clock in the mind of a communist does not point to the present. Why not? Because at the root of ideology there is this disjunction between the citizen (on the one hand) and the stakes of the present moment (on the other) hence the mock-resistance played out in 1984.

\section{Fukuyama's benign conception of ideology}

In his best-selling book The End of History and the Last Man (1992), Francis Fukuyama leans on the historical fact about the fall of totalitarianism in Eastern Europe to argue positively about the concomitant victory of liberal democracy which represents (according to Fukuyama) an "ideology of potentially universal validity" (Fukuyama 1992, 42). Fukuyama remains selfcongratulatory about the idea of history as a cumulative process which expands into a collective knowledge of the laws of cause and effect (ibid, 56-57):

As the Christian account of history makes clear, an "end of history" is implicit in the writing of all Universal Histories. The particular events of history can become meaningful only with respect to some larger end or goal, the achievement of which necessarily brings the historical process to a close. This final end of man is what makes all particular events potentially intelligible. (Ibid, 56)

Fukuyama lays out the claim that the end of history is synonymous with a hymn to man's full-fledged mastery of the laws of nature which will also reflect on his social and political progress (Fukuyama 1992, 57). Fukuyama's expression "end of history" comes into view as a metaphor of the crowning of man on top of his universe. He applies the term ideology indiscriminately to liberalism and to communism (Fukuyama 1992, 45) as what guides a community towards its highest good. What I make out hitherto is that what Fukuyama describes as ideology is nothing alarming: only a principle aiming at human concord: be it purely religious (Christianity, Islam, etc), or socio-economic (communism, liberalism).

Contrary to Decker, I am rather comforted by Fukuyama's benign meditation about the term ideology. I can see that Fukuyama has refigured ideology into the very locomotive of all phases of history until one end is achieved: which is the victory of the individual will over any will exterior to it. In the Fukuyama logic, the end of ideology is reached with man's liberation from totalitarianism. Decker does acknowledge the universal dimension in Fukuyama's idea about the end of history. However, he (Decker) eschews the bright side of ideology as what also permeates a felicitous turn of history. The now old-fashioned negativity of Decker's debate about ideology fails to distract Fukuyama's holistic pattern of 
history: a pattern which tracks down human progress synergistically as we traverse the necessary path of ideology:

Of the different types of regimes that have emerged in the course of human history, from monarchies and aristocracies, to religious theocracies, to the fascist and communist dictatorships of this century, the only form of government that has survived intact to the end of the twentieth century has been liberal democracy. (Fukuyama 1992, 45)

I need to make the precision that Fukuyama's conception of ideology is so original: precisely his reflection that the rise of liberal capitalism will not result in the ruin of ideology. On the contrary, Fukuyama acquaints us with the happy truth that ideology is purely a derivative of brainpower that has been progressing throughout the course of history towards an abdication of dogmas (religious or socio-economic): therefore of any world picture that is extrinsic to man's will. Here is Fukuyama again, from the same page:

What is emerging victorious, in other words, is not so much liberal practice, as the liberal idea [...] There is now no ideology with pretensions to universality that is in a position to challenge liberal democracy, and no universal principle of legitimacy other than the sovereignty of the people. (Fukuyama 1992, 45)

I am intrigued by the way Decker is so obstinate about hooking Fukuyama's standpoint to his own argument. By way of illustration (and on page 135 of Bloom's collection of articles), Decker misquotes Fukuyama's words about Islam: "Islam has virtually no appeal outside those areas that were culturally Islamic to begin with." But this is not what Fukuyama said. Following are Fukuyama's own words on Islam from his book The End of History (consulted by Decker in what is expected to be in full compliance with the rules of academic responsibility):

"The appeal of Islam is potentially
universal, reaching out to all men as
men, and not just to members of a
particular ethnic or national group."
(Fukuyama 1992,45)

Decker's mistake is not less ethical than technical. Besides, the occurrence of this misquote at an inaugural moment in his controlling argument (the way the article has been selected then edited by Harold Bloom within his collection of articles) enfeebles the credibility of Decker's entire hypothesis about an end to ideology. Despite the nuance made by Fukuyama few lines down in his book when admitting that Islam may pose a threat to liberal democracy, Decker's uncompromising aversion of ideology (what he erroneously claims to be an adherence to Fukuyama's sense of ideology) imperils his very academic integrity in a devastating way.

\section{Transmogrifying Orwell's Weltanschauung: Kirschner and Cain's idea of a dilemma}

At first blush, it seems that Orwell was wrestling to pin down his political opinion. However, his reserved attitude towards the political interpretation of his literature betrays an entire weltanschauung which resists the unctuous consecration of politics per se. In the course of his self-account, Orwell was obviously "on his guard" to borrow the expression by Paul Kirschner (qtd, in Bloom 2007, 155) who reports Orwell's self-defense against the deceptive interpretation of Animal Farm immediately as a mirror-image to any political ideology on his part:

"Capitalism leads to dole queues, the
scramble for markets, and war.
Collectivism leads to concentration
camps, leader worship, and war. There is
no way out of this unless a planned
economy can be somehow combined
with the freedom of the intellect, which
can only happen if the concept of right
and wrong is restored to politics." (iii
144)

Orwell introduces this apology of individuality as the new ethics that should never be at odds with the agenda of a politician. He solicits the more auspicious possibility of welcoming human frailties also as a pillar of a political design which "dissociat[es] Socialism from Utopianism" (iii 83):

"Perhaps some degree of suffering is
ineradicable from human life, perhaps
the choice before man is always a choice
of evils, perhaps even the aim of
Socialism is not to make the world
perfect but to make it better. All
revolutions are failures, but they are not
all the same failure." (iii 282) (qtd in
Bloom 2007, 155)

By making the precision that the suffering among the least privileged is an organic part of the biography of a people (any people), Orwell is also drawing attention to the depiction of this suffering as an evidence of his realism. Kirschner observes an additional merit in the point made by Orwell when the latter exalts failure as a step towards success: therefore as crucial to self-improvement in its larger humanistic sense. A problem with Kirschner, 
however, is that he levels the charge of being caught in a "dilemma" (qtd in Bloom 2007, 155) against Orwell as a result of this translocation in his discourse to and fro between Socialism and Capital democracy. Kirschner's confusion brings him close to another critic: William E. Cain who, in his article "Orwell's Perversity: An Approach to the Collected Essays", downgrades Orwell to the category of a perverse:

$$
\begin{aligned}
& \text { "Orwell is wrong: the } \\
& \text { persecutors do not deserve } \\
& \text { sympathy more than their } \\
& \text { victims. But, perversely, Orwell } \\
& \text { feels the need to add that twist, } \\
& \text { knowing that readers will } \\
& \text { respond to it as I have done." } \\
& \text { (Cain, qtd in Bloom 2007, 126) }
\end{aligned}
$$

Let us take Cain's value judgment as an antecedent to spell out a more generous truth about Orwell's discourse which he (Orwell) seems never to deny. Cain's misconception lies in his sympathetic fallacy which drags him into circumcising the rational method in Orwell's "I feel sorrier for the persecutors than for the victims" (Orwell 1968, 4: 267). One way to approach Orwell's avowed compassion with the persecutors is to align it with the author's more engaging inquiry into the dangers of a totalitarian government to the intellectual freedom of a people.

It is actually Orwell who hints at a dilemma nowhere but within the minds of the persecutors. The last mentioned, by censoring literature, will end up with a writing that is conformist but not spontaneous. However, if (in the opposite case) they give the floor to freedom of expression, they will have to face dissidence:

You can destroy spontaneity and produce a literature which is orthodox but feeble, or you can let people say what they choose and take the risk that some of them will utter heresies. There is no way out of that dilemma so long as books have to be written by individuals. That is why, in a way, I feel sorrier for the persecutors than for the victims. (Orwell 1968, 4: 267)

In observing that ideology is not less pestilent for the persecuted than for the persecutor, Orwell is anticipating those oncoming interpretations of his literature within a scope that is biased for Communism, Capitalism, or at best undecided between the two. Orwell explains to us that he did not employ a socio-political ideology in opposition to another. In essence, Orwell dramatizes tyranny in a metaphoric way: sometimes beyond the concern for the master/slave duality only to make room for his deeper literary-cum-humanistic end: which is the greater potential for the individual in how to explicate reality but also and mainly to pervert himself away from it.

\section{CONCLUSION}

Ideology is entrenched in a double pursuit. On the one hand, it is faithful to the irrational and overprotective will of the Inner Party. However, when dissent takes place, it veers towards its diametrical opposite as when capital democracy (allegedly a fair ally of the free, individual mind) also quickly transforms into a chastising force trapping its subjects in ruthless consumerism (next to a handful of other subtle forms of manipulation, espionage, etc) thus also rendering them as will-less. Conquering this fear of alienation happens in the Orwell optic thanks to the medium of art. Yet Orwell makes it clear that this conquest is never a full-fledged process unless we understand the limitedness of man essentially in light of his frailties. Control issues, staving off the possibility of thought, etc.: these are the stakes Orwell mentions never as a falsehood. In contradistinction to Decker's reinvention of the death of history as death of ideology, Orwell persists in acknowledging the creative power of the individual as a counterforce to the equally persisting strain of ideology.

\section{REFERENCES}

[1] Bloom, Harold, ed. (2007). Bloom's Modern Critical Views: George Orwell. New York: Chelsea House.

[2] Cain, William E. (2004). "Orwell's Perversity: An Approach to the Collected Essays" From George Orwell into the Twenty-first Century: pp. 215-228. Boulder: Paradigm Publishers.

[3] Decker, James M. (2004). Ideology. New York: Palgrave Macmillan.

[4] Fromm, Erich. (2008). The Sane Society. London: Routledge Classics.

[5] Fukuyama, Francis. (1992). The End of History and the Last Man. New York: Macmillan.

[6] Kirschner, Paul. (2004). "The Dual Purpose of Animal Farm" From The Review of English Studies 55, no. 222: pp. 759-786. London: OUP.

[7] Kroes, Rob. (1985). “A Nineteen Eighty-Foreboding: Orwell and the Entropy of Politics." from Nineteen EightyFour and the Apocalyptic Imagination in America. Ed. Kroes. Amsterdam: Free University Press, 85-96.

[8] Orwell, George. (1968). The Collected Essays, Journalism and Letters, ed. Sonia Orwell and Ian Angus. New York: Harcourt Brace Jovanovich.

[9] ------.-. (1983). Nineteen Eighty-Four. New York: Penguin Books. 